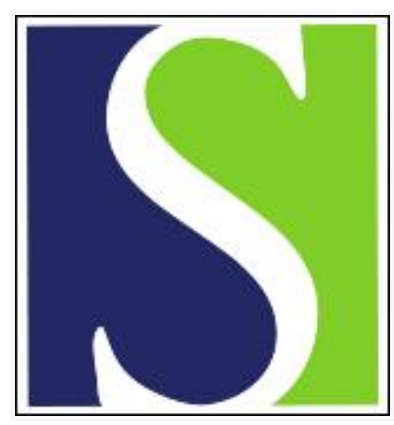

Scand J Work Environ Health 1988;14(6):356-365

https://doi.org/10.5271/sjweh.1907

Issue date: Dec 1988

Increased risk for primary liver cancer among women exposed to solvents.

by Hernberg S, Kauppinen T, Riala R, Korkala ML, Asikainen U

Affiliation: Institute of Occupational Health, Helsinki, Finland.

This article in PubMed: www.ncbi.nlm.nih.gov/pubmed/3212412 


\title{
Increased risk for primary liver cancer among women exposed to solvents ${ }^{1}$
}

\author{
by Sven Hernberg, MD, ${ }^{2}$ Timo Kauppinen, PhD, ${ }^{2}$ Riitta Riala, MSc(Eng), ${ }^{2}$ \\ Marja-Liisa Korkala, ${ }^{2}$ Ulla Asikainen, MD $^{3}$
}

\begin{abstract}
HERNBERG S, KAUPPINEN T, RIALA R, KORKALA M-L, ASIKAINEN U. Increased risk for primary liver cancer among women exposed to solvents. Scand J Work Environ Health 14 (1988) 356-365. An earlier case-referent study by the same authors [Int Arch Occup Environ Health 54 (1984) 147-153] reported that solvent-exposed women, but not men, had an increased risk for primary liver cancer. The present study was undertaken to verify these results. The relatives of deceased patients, ie, 377 liver cancer cases, 385 coronary infarction referents, and 476 stomach cancer referents, responded to a questionnaire on past employment and potentially relevant covariables, the response rates being $71.7,72.7$, and $69.0 \%$, respectively. The information was assessed for solvent exposure by two occupational hygienists without knowledge of the patients' diagnoses. Seven male and seven female liver cancer cases had been exposed to solvents, the odds ratio being $<1$ for the men but $>3$ for the women irrespective of the reference group used for comparison. The results confirm the authors' earlier findings. When both materials were combined, the odds ratio was 7.8 for the female liver cancer cases as compared with the infarction referents. In the combined material, nine female liver cancer cases, two stomach cancer referents, but no infarction referent had had at least probable exposure to chlorinated hydrocarbons. Such exposure was rare among all of the men in the study. This finding may explain why the increased liver cancer risk occurred only for the women, although a sex difference in sensitivity cannot be completely ruled out.
\end{abstract}

Key terms: case-referent study, chlorinated hydrocarbons, ethyl alcohol.

We have earlier found (10) an increased risk of primary liver cancer among women exposed to organic solvents. Other researchers have obtained similar results, both for men $(6,9,14)$ and for women $(2,14)$, but also nonpositive studies have been published $(1,3,7,13)$.

The results of our first study were inconsistent in the sense that a connection between solvent exposure and liver cancer occurred for women only, while no such risk was discernible for men (10). The results could have been due to a true effect, but they could also have been a chance finding or could have reflected an undetected systematic error. We concluded that a new study was needed to determine which of these explanations was the most likely, and the present study was initiated with this objective. We diminished the possibilities of a chance finding and bias by using a larger sample size and two different reference groups, one with coronary infarction, as in the previous study, and the other with another type of cancer.

\footnotetext{
1 Part of the results of this study were presented at the Sixth Conference on Epidemiology in Occupational Health, Stockholm, 15-18 August 1988 .

2 Institute of Occupational Health, Helsinki, Finland.

3 Jorvi Hospital, Espoo, Finland.
}

Reprint requests to: Professor S Hernberg, Institute of Occupational Health, Topeliuksenkatu 41 a A, SF-00250 Helsinki, Finland.

\section{Subjects and methods}

The 618 persons with primary liver cancer [International Classification of Diseases (ninth revision) 155.0] reported to the Finnish Cancer Register in 1976, 1977, 1978 , and 1981 were first listed as cases. (The previous study investigated the liver cancer cases reported in 1979 and 1980.) Persons with cancers of multiple sites, including the liver, were excluded. Only five patients were alive when the study started. (See figure 1.) They were excluded so that the quality of the information could be kept homogeneous. No relatives could be found for 87 of the liver cancer patients, and these patients were also excluded.

A relative could be located for 526 deceased liver cancer patients, and a questionnaire was sent to each of these relatives. The data obtained with the questionnaire formed the basic material on the cases. Table 1 shows the kinship of the responding relatives, as well as their response rates. After the initial response and one reminder 377 questionnaires had been returned by the relatives of the cases, the total response rate therefore being $71.7 \%$. Thirty-three cases had to be omitted from this material however because the diagnosis of primary liver cancer seemed incorrect or could not be confirmed. The final material was hence 344 liver cancer cases among 178 men and 166 women (figure 1).

Table 2 shows the verification of the liver cancer diagnoses, and table 3 gives the distribution for the histological types of cancer. For 61 cases the diagnosis was based on clinical history only. 


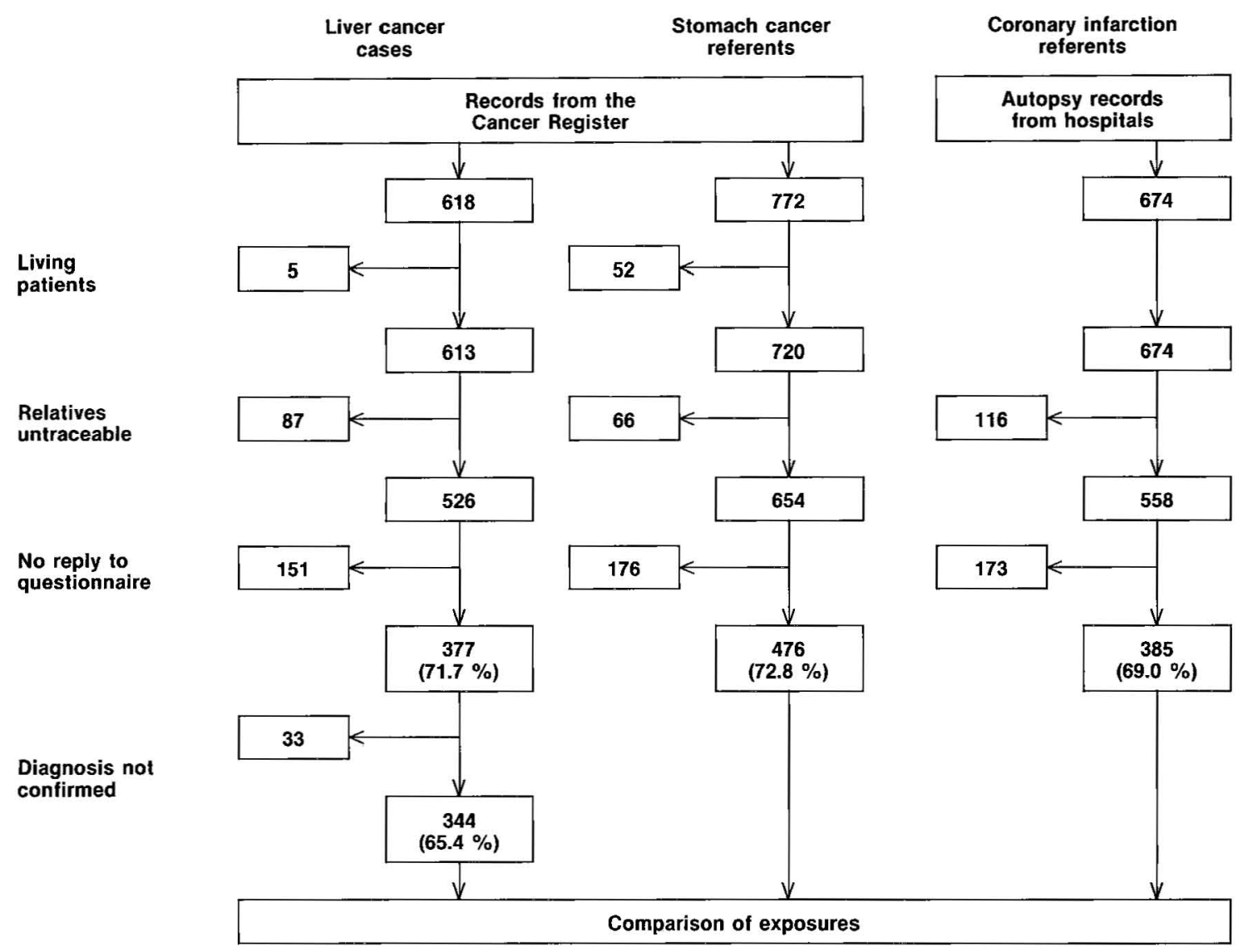

Figure 1. Flow chart of the study.

Table 1. Response to the postal questionnaire. Percentages calculated after those persons with untraceable relatives were excluded.

\begin{tabular}{ccccccc} 
& Men $(\%)$ & & & \multicolumn{3}{c}{ Women $(\%)$} \\
\cline { 6 - 7 } Liver & Stomach & Coronary & & Liver & Stomach & Coronary \\
cancer & cancer & infarction & & cancer & cancer & infarction \\
cases & referents & referents & & cases & referents & referents \\
$(\mathrm{N}=178)$ & $(\mathrm{N}=272)$ & $(\mathrm{N}=218)$ & & $(\mathrm{N}=166)$ & $(\mathrm{N}=204)$ & $(\mathrm{N}=167)$ \\
\hline
\end{tabular}

Respondent

\begin{tabular}{lrrrrrr} 
Spouse & 55 & 50 & 65 & 14 & 14 & 16 \\
Child & 29 & 38 & 23 & 63 & 60 & 59 \\
Sibling & 6 & 6 & 6 & 10 & 12 & 12 \\
Other & 10 & 6 & 6 & & & 15 \\
Response rate & & & & 29 & 39 & 13 \\
First contact & 25 & 42 & 33 & 36 & 36 & 28 \\
Second contact & 33 & 35 & 32 & & & \\
\hline
\end{tabular}

Two different reference groups were used. As in our first study, coronary infarction was chosen as one of the reference diagnoses. Infarction patients who had died in 1977 were frequency matched with the cases with regard to sex, age, and hospital of diagnosis. In all, 674 coronary infarction patients were selected as referents. Of them, 116 had no or untraceable relatives and had to be excluded. The questionnaire was sent to the relatives of the remaining 558 infarction patients and was returned by 385 of them (figure 1). The response rate was thus $69.0 \%$. The second reference group was formed of patients with stomach cancer reported to the Cancer Register in 1977. Altogether 772 cancer patients were randomly selected from the register. Fifty-two of them were alive and were excluded to ensure the comparability of the information. The relatives of 66 patients were untraceable. A questionnaire was sent to the relatives of the remaining 654 
Table 2. Verification of the liver cancer diagnoses.

\begin{tabular}{lrrrrrr}
\hline \multirow{2}{*}{$\begin{array}{l}\text { Type of } \\
\text { verification }\end{array}$} & \multicolumn{2}{c}{ Men } & & \multicolumn{2}{c}{ Women } \\
\cline { 2 - 3 } \cline { 6 - 7 } & $\mathrm{N}$ & $\%$ & & $\mathrm{~N}$ & $\%$ \\
\hline Thin needle biopsy & 2 & 1.1 & & 1 & 0.6 \\
Coarse needle biopsy & 16 & 9.0 & & 8 & 4.8 \\
Laparatomy biopsy & 36 & 20.2 & & 45 & 27.1 \\
Autopsy specimen & 91 & 51.1 & & 84 & 51.0 \\
No histology available & 33 & 19.0 & & 28 & 17.0 \\
\hline Total & 178 & 100 & & 166 & 100 \\
\hline
\end{tabular}

Table 3. Distribution of the histological diagnoses of the liver cancer cases.

\begin{tabular}{|c|c|c|c|c|}
\hline \multirow{2}{*}{ Diagnosis } & \multicolumn{2}{|c|}{ Men } & \multicolumn{2}{|c|}{ Women } \\
\hline & $\mathrm{N}$ & $\%$ & $\mathrm{~N}$ & $\%$ \\
\hline Hepatocellular carcinoma & 104 & 58.4 & 70 & 42.2 \\
\hline Cholangiocarcinoma & 21 & 11.8 & 42 & 25.3 \\
\hline Anaplastic carcinoma & 10 & 5.6 & 11 & 6.6 \\
\hline Angiosarcoma & 1 & 0.6 & 1 & 0.6 \\
\hline Classification uncertain ${ }^{a}$ & 9 & 5.1 & 14 & 8.4 \\
\hline No histology available & 33 & 18.5 & 28 & 16.9 \\
\hline Total & 178 & 100 & 166 & 100 \\
\hline
\end{tabular}

Table 4. Age distribution of the cases and referents by sex.

\begin{tabular}{|c|c|c|c|c|c|c|}
\hline \multirow[b]{2}{*}{$\begin{array}{l}\text { Age group } \\
\text { (years) }\end{array}$} & \multicolumn{3}{|c|}{ Males $(\%)$} & \multicolumn{3}{|c|}{ Females $(\%)$} \\
\hline & $\begin{array}{c}\text { Liver } \\
\text { cancer } \\
\text { cases } \\
(\mathrm{N}=178)\end{array}$ & $\begin{array}{l}\text { Stomach } \\
\text { cancer } \\
\text { referents } \\
(N=272)\end{array}$ & $\begin{array}{l}\text { Coronary } \\
\text { infarction } \\
\text { referents } \\
(\mathrm{N}=218)\end{array}$ & $\begin{array}{c}\text { Liver } \\
\text { cancer } \\
\text { cases } \\
(N=166)\end{array}$ & $\begin{array}{l}\text { Stomach } \\
\text { cancer } \\
\text { referents } \\
(N=204)\end{array}$ & $\begin{array}{l}\text { Coronary } \\
\text { infarction } \\
\text { referents } \\
(\mathrm{N}=167)\end{array}$ \\
\hline $\begin{array}{l}\leq 39 \\
40-44 \\
45-49 \\
50-54 \\
55-59 \\
60-64 \\
65-69 \\
70-74 \\
75-79 \\
80-84 \\
\geq 85\end{array}$ & \begin{tabular}{r|}
0.6 \\
0.6 \\
3.3 \\
4.4 \\
12.2 \\
16.7 \\
16.7 \\
20.0 \\
22.8 \\
9.4 \\
7.2 \\
2.8
\end{tabular} & \begin{tabular}{r|}
1.8 \\
1.8 \\
5.2 \\
6.6 \\
10.3 \\
12.5 \\
12.1 \\
22.1 \\
16.5 \\
13.2 \\
7.4 \\
2.6
\end{tabular} & $\begin{array}{r}3.2 \\
1.4 \\
3.7 \\
4.6 \\
12.8 \\
15.1 \\
26.2 \\
18.4 \\
5.5 \\
6.9 \\
2.3\end{array}$ & $\begin{array}{r}1.8 \\
0.6 \\
1.8 \\
6.1 \\
7.3 \\
10.4 \\
15.2 \\
15.2 \\
17.1 \\
16.5 \\
7.9\end{array}$ & $\begin{array}{r}2.5 \\
0.0 \\
2.9 \\
5.4 \\
7.4 \\
6.9 \\
13.2 \\
17.7 \\
19.1 \\
15.2 \\
9.8\end{array}$ & $\begin{array}{r}0.6 \\
0.6 \\
2.4 \\
3.6 \\
10.2 \\
11.4 \\
13.2 \\
22.2 \\
18.0 \\
10.8 \\
7.2\end{array}$ \\
\hline $\begin{array}{l}\text { Mean age } \\
\text { (years) }\end{array}$ & 67.0 & 66.0 & 65.1 & 70.3 & 71.1 & 70.3 \\
\hline
\end{tabular}

stomach cancer referents and was returned by 476 of them. The response rate was thus $72.8 \%$.

Table 4 shows the age distribution of the cases and referents.

The questionnaire could not be very detailed in that, according to our previous experience, relatives of deceased patients are in general not aware of details of the patients' occupational history, such as exposure to specific chemicals. Therefore the key issue of the questionnaire was a chronological list of employers, work sites, occupations, and calendar years of work.

Questions on the use of alcohol, tobacco, coffee, tea, and medicines and on leisure-time activities were also included in the questionnaire. Alcohol consumption was classified into (i) not at all or occasional, (ii) moderate, and (iii) heavy, alcohol problems. The relatives of the female patients were asked about the use of oral contraceptives, but, because of the age (old) distribution of the patients, only very few of them had ever used such preparations.

The case or reference status was obscured from the questionnaires, which were evaluated by two occupational hygienists (TK and RR) without knowledge of whether the patient was a case or a referent. One hygienist scrutinized 557 of the questionnaires, and the other examined 688 . They evaluated the occupational histories regarding the likelihood of including not only exposure to solvents, but also exposure to a number of other agents. Only solvent exposure has been considered in this report.

The evaluation of potential solvent exposure was first based on the industries, the workplaces, and the occupational titles reported for the patients and on any more detailed information of the type of work provided by the relatives. The persons with jobs entailing potential exposure to solvents were then identified on the basis of the hygienists' knowledge of the extent and intensity of exposure in the various industries and occupations. If the solvent exposure could not be determined from the form, it was checked by telephone, either with a representative of the workplace in question, if it still existed, or with the relative of the patient. Nearly 50 workplaces were successfully contacted for more detailed information on exposure. The sources of information were either the occupational health unit, the safety engineer, or the supervisor of the department in question. A number of small companies had ceased to exist, especially shoe factories. In such cases the available information on products used in the 1950s and 1960s, as well as avail- 
able facts on earlier work methods, was mainly gathered from still existing firms and used as a proxy in the exposure evaluation. No exposure that had occurred less than 10 years before the diagnosis was taken into account in order to allow for a latency period. Both continuous and intermittent use of solvents was classified as "exposure." However, uncertain, shortterm exposures which had occurred irregularly, as for instance "washing of machine parts during repair of one's own car" or "occasional use of solvents in the cleaning of homes or offices," were not included.

Exposures were divided into three classes, "heavy," "'moderate," and "light." Exposure was classified as heavy when it was estimated to have been higher than the 1986 threshold limit value (TLV) of the American Conference of Governmental Industrial Hygienists. Continuous or intermittent exposure that was estimated to have been at least half of the TLV but not above it was classified as moderate. The exposure of persons who had worked in a heavy-exposure industry, but whose work tasks could not be fully clarified, were classified as moderately exposed. Exposure was considered to be light when exposure was certain but the level of exposure had probably been less than half the TLV. In addition, there was a category with potential exposure which could not be certified. Such exposures, or those which were considered as having been too low to fit into the "exposed"' classes, were classified as "uncertain." This classification was given to 25 liver cancer cases, 30 stomach cancer referents, and 39 coronary infarction referents.

The exposure classification was mainly based on estimates because the exposures had taken place between the 1920s and 1968. However, some data on measurements of earlier exposure levels were found in the files of the Finnish Institute of Occupational Health. In dry cleaning, the range of exposure to tri- and perchloroethylene had been $52-173 \mathrm{ppm}$ and $34-600 \mathrm{ppm}$, respectively, according to monitoring with personal samplers in the 1950s. Exposure to benzene occurred in the shoe industry until the mid-1950s; personal monitoring performed by the Institute indicated concentrations between 138 and $470 \mathrm{ppm}$ during the glueing of shoes with an adhesive containing benzene as the main solvent. According to available product data on rubber adhesives, exposure to chlorinated hydrocarbons was also common in shoe manufacturing until the late 1960s. Especially chloroprene adhesives have contained chlorinated hydrocarbons, among them trichloroethylene and carbon tetrachloride. Furthermore, before being painted, the shoes were usually cleaned with trichloroethylene.

To decrease the bias caused by any misclassification of exposures, we either classified the patients with uncertain exposures as unexposed or excluded them from the analysis. Combining uncertain exposures with the exposed category was not regarded as appropriate because it would have biased the odds ratio (OR) estimates towards unity. (See, eg, reference 4.) This ef- fect may be strong whenever exposure is rare among a study population, which was the case in the present study.

To achieve interrater consistency in the evaluation of exposures, the hygienists discussed and agreed upon the probability and intensity of exposure in various jobs both prior to and during the evaluation. Accordingly, one hygienist classified $3.6 \%$ of the subjects as having been exposed, and the corresponding figure for the other was $3.9 \%$. Exposure to several agents other than solvents was coded as well, the occupational histories being surveyed for 50 agents or factors by means of a job-exposure matrix. The results from these analyses will be published in a separate paper (Kauppinen et al, under preparation).

The likelihood-based OR estimates and the associated $90 \%$ confidence intervals $(90 \% \mathrm{CI})$ were calculated according to Cornfield (5). The stratified analysis was based on the same method as extended by Gart (8).

\section{Results}

A total of 14 liver cancer cases (seven men, seven women) had been exposed to solvents, of them nine heavily, two moderately, and three lightly. Seventeen (14 men, 3 women) stomach cancer referents had been exposed, of them six heavily, eight moderately, and three lightly. Of the coronary infarction referents, 16 (14 men, 2 women) had been exposed, of them six heavily, eight moderately, and two lightly. The OR estimates and $90 \%$ confidence intervals are shown in table 5 . The risk for the men was considerably lower than unity, although not statistically significantly so. When uncertain exposures were excluded for both the cases and the referents, the OR for the women indicated a more than threefold excess risk, as compared with each reference group separately or both groups combined (table 5). These results remained essentially the same when uncertain exposures were combined with no exposure.

Table 6 shows that alcohol use was clearly more common among the men with liver cancer than among the men in the reference groups and also that there was a dose-response relationship. For the women there was no clear tendency in this respect.

Table 5. Odds ratios (OR) and $90 \%$ confidence intervals $(90 \%$ $\mathrm{Cl}$ ) for the association between primary liver cancer and solvent exposure among the male and female liver cancer cases separately (uncertain exposures excluded), determined for the two reference groups separately and combined. Allowance has been made for a minimum latency of 10 years.

\begin{tabular}{llllll}
\hline \multirow{2}{*}{ Reference group } & \multicolumn{4}{c}{ Liver cancer cases } \\
\cline { 2 - 3 } & \multicolumn{2}{c}{ Men } & & \multicolumn{2}{c}{ Women } \\
\cline { 2 - 3 } \cline { 5 - 6 } & OR & $90 \% \mathrm{Cl}$ & & OR & $90 \% \mathrm{Cl}$ \\
\hline Stomach cancer & 0.7 & $0.3-1.5$ & & 3.2 & $1.1-9.4$ \\
Coronary infarction & 0.6 & $0.3-1.2$ & & 3.7 & $1.0-13$ \\
Both groups combined & 0.6 & $0.3-1.3$ & & 3.4 & $1.3-8.6$ \\
\hline
\end{tabular}


Table 6. Odds ratios (OR) and $90 \%$ confidence intervals (90\% Cl) for the association between primary liver cancer and heavy and moderate alcohol use among the male and female Iiver cancer cases separately, determined for the two reference groups separately and combined.

\begin{tabular}{|c|c|c|c|c|c|c|c|c|}
\hline \multirow{4}{*}{ Reference group } & \multicolumn{8}{|c|}{ Liver cancer cases } \\
\hline & \multicolumn{4}{|c|}{ Men } & \multicolumn{4}{|c|}{ Women } \\
\hline & \multicolumn{2}{|c|}{$\begin{array}{l}\text { Heavy } \\
\text { alcohol use } \\
(N=34)\end{array}$} & \multicolumn{2}{|c|}{$\begin{array}{l}\text { Moderate } \\
\text { alcohol use } \\
(\mathrm{N}=81)\end{array}$} & \multicolumn{2}{|c|}{$\begin{array}{l}\text { Heavy } \\
\text { alcohol use } \\
(\mathrm{N}=1)\end{array}$} & \multicolumn{2}{|c|}{$\begin{array}{l}\text { Moderate } \\
\text { alcohol use } \\
(N=16)\end{array}$} \\
\hline & OR & $90 \% \mathrm{CI}$ & OR & $90 \% \mathrm{Cl}$ & OR & $90 \% \mathrm{Cl}$ & OR & $90 \% \mathrm{Cl}$ \\
\hline $\begin{array}{l}\text { Stomach cancer } \\
\text { Coronary infarction } \\
\text { Both groups combined }\end{array}$ & $\begin{array}{l}4.5 \\
2.6 \\
3.4\end{array}$ & $\begin{array}{l}2.5-8.2 \\
1.5-4.7 \\
2.1-5.7\end{array}$ & $\begin{array}{l}1.7 \\
1.5 \\
1.6\end{array}$ & $\begin{array}{l}1.2-2.5 \\
1.0-2.2 \\
1.1-2.3\end{array}$ & $\begin{array}{l}0.7 \\
1.0 \\
0.8\end{array}$ & $\begin{array}{l}0.0-7.3 \\
0.0-27 \\
0.0-6.6\end{array}$ & $\begin{array}{l}1.6 \\
1.2 \\
1.4\end{array}$ & $\begin{array}{l}0.8-3.3 \\
0.6-2.5 \\
0.8-2.6\end{array}$ \\
\hline
\end{tabular}

Table 7. Comparison between the solvent-exposed and unexposed women and men with primary liver cancer according to reported alcohol use. The alcohol use of six unexposed women and two unexposed men was unknown.

\begin{tabular}{|c|c|c|c|c|c|}
\hline \multirow{3}{*}{$\begin{array}{l}\text { Liver } \\
\text { cancer } \\
\text { cases }\end{array}$} & \multirow{3}{*}{$\begin{array}{l}\text { Number } \\
\text { of } \\
\text { subjects }\end{array}$} & \multicolumn{4}{|c|}{ Alcohol use } \\
\hline & & \multicolumn{2}{|c|}{ Heavy } & \multicolumn{2}{|c|}{ Moderate } \\
\hline & & $N$ & $\%$ & $N$ & $\%$ \\
\hline \multicolumn{6}{|l|}{ Women } \\
\hline $\begin{array}{l}\text { Exposed } \\
\text { Unexposed }\end{array}$ & $\begin{array}{r}7 \\
137\end{array}$ & $\begin{array}{l}0 \\
1\end{array}$ & $\begin{array}{l}0 \\
1\end{array}$ & $\begin{array}{r}0 \\
16\end{array}$ & $\begin{array}{r}0 \\
12\end{array}$ \\
\hline \multicolumn{6}{|l|}{ Men } \\
\hline $\begin{array}{l}\text { Exposed } \\
\text { Unexposed }\end{array}$ & $\begin{array}{r}7 \\
162\end{array}$ & $\begin{array}{r}2 \\
34\end{array}$ & $\begin{array}{l}29 \\
21\end{array}$ & $\begin{array}{r}1 \\
81\end{array}$ & $\begin{array}{l}14 \\
50\end{array}$ \\
\hline
\end{tabular}

In controlling for possible confounding by alcohol use, the results should be adjusted for this variable. As shown in table 7, none of the female cases exposed to solvents had used alcohol heavily or even moderately according to the information provided by the relative contacted, as compared with $15 \%$ of the unexposed female cases. Of the exposed male cases, three $(43 \%)$ had used alcohol heavily or moderately, while $69 \%$ of the unexposed male cases had had such habits. These results suggest that any confounding effect of alcohol use on our data must be negative and that therefore, such confounding could not explain the high OR estimates determined for the women. On the contrary, the OR values are rather underestimates of the true effect. Because of statistical restrictions (no exposed female cases with moderate or heavy alcohol use) formal adjustment for alcohol use could not be done for the women. However, when the comparison was restricted to those women who had used alcohol occasionally or not at all, the odds ratios were as high as 9.7 (stomach cancer) and 7.2 (coronary infarction), respectively. For the men, the odds ratios for solvent exposure rose only minimally when adjusted for alcohol use.

Altogether 52 cases ( 30 men, 22 women) had verified cirrhosis of the liver. Of the solvent-exposed cases, two men and two women had verified cirrhosis. Of the female cases with solvent exposure one was due to chronic hepatitis, while the other was unclassifiable.
Notations of hepatitis were rare in the patient records. Only two cases were positive to Australia antigen, and two others had a history of hepatitis B infection.

A summary of the exposure histories of the female cases and referents is given in table 8 . The exposure had usually been of a mixed type. Three cases had definitely been exposed to chlorinated hydrocarbons, and for two such exposure had been possible. None of the coronary infarction referents and two stomach cancer referents had had such exposure according to the blind assessment.

The exposure pattern for the men differed (table 9). The overwhelming majority of the exposed male cases and referents had been painters, an occupation which does not generally entail exposure to chlorinated hydrocarbons. Only two of the male cases and two of the male infarction referents but none of the male stomach cancer referents had worked in dry cleaning, a process in which exposure to chlorinated hydrocarbons was the rule in Finland until the end of the 1970s.

Coffee or tea drinking or the use of various drugs did not show any consistent association with liver cancer. A slight excess of cases could be observed among the men who had smoked more than one pack of cigarettes per day, but for the women there was no consistent excess (table 10).

Table 11 presents the distribution of some leisuretime activities among the cases and referents. Slightly more female cases than female referents had been engaged in some activities entailing possible exposure to solvents, such as carpentry and lacquering, plastics or reinforced plastics work (styrene), and leather work (solvents for glues). The male cases and referents showed no differences.

\section{Discussion}

The results of the present study confirm our previous finding of a connection between exposure to solvents and primary liver cancer in women (10). In our previous study six of 62 female cases compared to none of 92 female referents had been exposed to solvents. In the present study seven of 166 female cases and five of 371 female infarction referents had had past exposure to solvents; the direction of the result was thus 
Table 8. Histological diagnosis and exposure data for the female liver cancer cases and referents exposed to solvents.

\begin{tabular}{|c|c|c|c|c|c|}
\hline $\begin{array}{l}\text { Casel } \\
\text { referent } \\
\text { status }\end{array}$ & $\begin{array}{l}\text { Histo- } \\
\text { logya }^{a}\end{array}$ & Period & $\begin{array}{l}\text { Duration } \\
\text { (years) }\end{array}$ & $\begin{array}{l}\text { Estimated } \\
\text { intensity }\end{array}$ & Type of solvent and job \\
\hline Case & $\mathrm{H}$ & $1942-1948$ & 6 & Heavy & $\begin{array}{l}\text { Chlorinated hydrocarbons during dry } \\
\text { cleaning }\end{array}$ \\
\hline Case & C & $1947-1972$ & 25 & Heavy & $\begin{array}{l}\text { Benzene and chlorinated and aromatic } \\
\text { hydrocarbons during glueing in a shoe } \\
\text { factory }\end{array}$ \\
\hline Case & $?$ & $1916-1961$ & 45 & Moderate & $\begin{array}{l}\text { Mixture of hydrocarbons, toluene, } \\
\text { possibly benzene, and chlorinated hydro- } \\
\text { carbons in a shoe factory }\end{array}$ \\
\hline Case & $\mathbf{H}$ & $\begin{array}{l}\text { about } \\
1930-1960\end{array}$ & about 30 & Moderate & $\begin{array}{l}\text { Hydrocarbons, among them trichloro- } \\
\text { ethylene, during the printing and } \\
\text { washing of cylinders in a relief printing } \\
\text { office }\end{array}$ \\
\hline Case & C & $\begin{array}{l}\text { In the } \\
1950 \mathrm{~s}\end{array}$ & $2-4$ & Light & $\begin{array}{l}\text { Mixed solvents in a joinery shop, and } \\
\text { possibly chlorinated hydrocarbons in a } \\
\text { laundry }\end{array}$ \\
\hline Case & $\mathrm{H}$ & $1933-1974$ & 41 & Light & $\begin{array}{l}\text { Toluene and other solvents of felt-tip } \\
\text { pens during map drawing and washing } \\
\text { of plastics with gasoline }\end{array}$ \\
\hline Case & $\mathrm{H}$ & Unknown & Long & Light & $\begin{array}{l}\text { Life-long use of thinners and lacquers } \\
\text { during leisure-time activities, cleaning in } \\
\text { a laboratory }\end{array}$ \\
\hline $\begin{array}{l}\text { Stomach } \\
\text { cancer }\end{array}$ & . & $\begin{array}{l}1928-1941 \& \\
1947-1963\end{array}$ & 29 & Heavy & $\begin{array}{l}\text { Handling of rubber glues in a shoe } \\
\text { factory and exposure to benzene, other } \\
\text { hydrocarbons, and possibly chlorinated } \\
\text { hydrocarbons }\end{array}$ \\
\hline $\begin{array}{l}\text { Stomach } \\
\text { cancer }\end{array}$ & . & $\begin{array}{l}\text { Probably } \\
\text { from the } \\
1920 \text { s }\end{array}$ & Unknown & Moderate & $\begin{array}{l}\text { Handling of rubber glues in a shoe } \\
\text { factory, including benzene, other } \\
\text { hydrocarbons, and possibly halogenated } \\
\text { hydrocarbons }\end{array}$ \\
\hline $\begin{array}{l}\text { Stomach } \\
\text { cancer }\end{array}$ & $\cdot$ & $1920-1955$ & about 35 & Light & $\begin{array}{l}\text { Cleaning in a pharmaceutical factory } \\
\text { and exposure to solvent mixtures }\end{array}$ \\
\hline $\begin{array}{l}\text { Coronary } \\
\text { infarction }\end{array}$ & $\cdot$ & $1951-1968$ & 17 & Heavy & $\begin{array}{l}\text { Cleaning of paint brushes and pots with } \\
\text { thinners and turpentine in a printing } \\
\text { shop }\end{array}$ \\
\hline $\begin{array}{l}\text { Coronary } \\
\text { infarction }\end{array}$ & $\cdot$ & $\begin{array}{l}1965-1968 \& \\
1970-1974\end{array}$ & 7 & Light & $\begin{array}{l}\text { Xylene in a pathological laboratory } \\
\text { (laboratory assistant) }\end{array}$ \\
\hline
\end{tabular}

a $\mathrm{H}=$ hepatocellular, $\mathrm{C}=$ cholangiocarcinoma.

similar to that of the first study. Combining both materials yields an OR of 7.8 (95\% CI 1.6-50). Interestingly, also the results for the men were consistent in both studies, although in the opposite direction. In our first study the men had an OR of 0.5 ; in the present one the OR estimates ranged between 0.5 and 0.7 , depending on the manner in which uncertain exposure was classified and on which reference group was used for comparison.

In our first study we speculated on the reasons why solvent exposure was connected with an increased risk of liver cancer among the women, but not among the men (10). We suggested three explanations, ie, a chance finding, some undetected systematic error, or a true sex difference in sensitivity.

The sample size of our new study was large enough to lessen the likelihood of a chance finding, especially since the results of both studies had the same direction. The OR of both studies combined, furthermore, is so convincing that a chance finding is a highly unlikely explanation. Someone may argue that combining the results of a "hypothesis-generating" and a "hy- pothesis-testing"' study is incorrect. However, the two studies used the same methodology, they had the same source of material, and they utilized cases from the same time period. Besides, even when viewed separately, the results of both studies are statistically significant.

A systematic error can arise from selection, information bias, or confounding. Because the source material comprised all liver cancer patients of the entire country during four years (and two more years in our first study), a priori selection is not likely. Some selection could have arisen from a slight overrepresentation of farmers among the stomach cancer referents. Farmers were not classified as exposed to solvents, and the selection involved might have caused a weak positive bias. However, for the infarction referents, there was no overrepresentation of farmers, and the results were essentially the same irrespective of which reference group was used for comparison.

Selective nonresponse could be another reason for bias. We had two major reasons for loss of material. The first was unsuccessful tracing of the relatives of 
Table 9. Histological diagnosis and exposure data for the male liver cancer cases and referents exposed to solvents.

\begin{tabular}{|c|c|c|c|c|c|}
\hline $\begin{array}{l}\text { Casel } \\
\text { referent } \\
\text { status }\end{array}$ & $\begin{array}{l}\text { Histo- } \\
\text { logy }^{a}\end{array}$ & Period & $\begin{array}{l}\text { Duration } \\
\text { (years) }\end{array}$ & $\begin{array}{l}\text { Estimated } \\
\text { intensity }\end{array}$ & Type of solvent and job \\
\hline Case & $\mathrm{H}$ & $1944-1971$ & 27 & Heavy & $\begin{array}{l}\text { Carbon disulfide in viscose manu- } \\
\text { facturing }\end{array}$ \\
\hline Case & AS & $1929-1944$ & 16 & Heavy & $\begin{array}{l}\text { Synthesis of mustard gas, carbon } \\
\text { disulfide, and carbon tetrachloride in } \\
\text { laboratory work }\end{array}$ \\
\hline Case & H & $1958-1978$ & 20 & Heavy & $\begin{array}{l}\text { Aromatic hydrocarbons and other } \\
\text { solvents in printing (printer) }\end{array}$ \\
\hline Case & $A C$ & $1940-$ & Long & Heavy & Paint solvents as a painter \\
\hline Case & $\mathrm{H}$ & $1920-$ & Long & Heavy & Paint solvents as a painter \\
\hline Case & $\mathrm{H}$ & $1920-$ & Long & Heavy & Paint solvents as a painter \\
\hline Case & $\mathrm{H}$ & $1926-1953$ & 27 & Heavy & $\begin{array}{l}\text { Many solvents as a chemist in a } \\
\text { university teaching laboratory }\end{array}$ \\
\hline $\begin{array}{l}\text { Stomach } \\
\text { cancer }\end{array}$ & . & $1956-1964$ & 8 & Heavy & Paint solvents in paint manufacturing \\
\hline $\begin{array}{l}\text { Stomach } \\
\text { cancer }\end{array}$ & . & $1968-1977$ & 9 & Heavy & Paint solvents as a painter \\
\hline $\begin{array}{l}\text { Stomach } \\
\text { cancer }\end{array}$ & . & $1951-1977$ & 26 & Heavy & Paint solvents in paint manufacturing \\
\hline $\begin{array}{l}\text { Stomach } \\
\text { cancer }\end{array}$ & $\cdot$ & $1930-$ & Unknown & Heavy & Paint solvents as a painter \\
\hline $\begin{array}{l}\text { Stomach } \\
\text { cancer }\end{array}$ & . & $1920-$ & Unknown & Heavy & Paint solvents as a painter \\
\hline $\begin{array}{l}\text { Stomach } \\
\text { cancer }\end{array}$ & . & $1929-1934$ & 5 & Light & $\begin{array}{l}\text { Various solvents, possibly chlorinated } \\
\text { hydrocarbons, as a shoemaker and in } \\
\text { shoe repair work }\end{array}$ \\
\hline $\begin{array}{l}\text { Stomach } \\
\text { cancer }\end{array}$ & . & $1920-1941$ & 21 & Light & $\begin{array}{l}\text { Paint solvents during painting during } \\
\text { leisure time (farming as main } \\
\text { occupation) }\end{array}$ \\
\hline $\begin{array}{l}\text { Stomach } \\
\text { cancer }\end{array}$ & $\cdot$ & $1911-1975$ & 64 & Light & $\begin{array}{l}\text { Various solvents, possibly chlorinated } \\
\text { hydrocarbons, as a shoemaker and in } \\
\text { shoe repair work }\end{array}$ \\
\hline $\begin{array}{l}\text { Stomach } \\
\text { cancer }\end{array}$ & . & $1949-1975$ & 26 & Light & Paint solvents as a carpenter and joiner \\
\hline $\begin{array}{l}\text { Stomach } \\
\text { cancer }\end{array}$ & . & $1930-$ & Unknown & Light & Paint solvents as a carpenter \\
\hline $\begin{array}{l}\text { Stomach } \\
\text { cancer }\end{array}$ & $\cdot$ & $1920-1960$ & 40 & Light & $\begin{array}{l}\text { Paint solvents in, among others, paint- } \\
\text { ing and decorating }\end{array}$ \\
\hline $\begin{array}{l}\text { Stomach } \\
\text { cancer }\end{array}$ & . & $1940-$ & Unknown & Light & Paint solvents as a carpenter (painter) \\
\hline $\begin{array}{l}\text { Stomach } \\
\text { cancer }\end{array}$ & $\cdot$ & $1940-$ & Unknown & Light & Paint solvents as a joiner \\
\hline $\begin{array}{l}\text { Stomach } \\
\text { cancer }\end{array}$ & - & $1945-1956$ & 11 & Light & Paint solvents as a carpenter (painter) \\
\hline $\begin{array}{l}\text { Coronary } \\
\text { infarction }\end{array}$ & $\cdot$ & $1920-$ & Unknown & Heavy & Paint solvents as a painter \\
\hline $\begin{array}{l}\text { Coronary } \\
\text { infarction }\end{array}$ & . & $1930-$ & Unknown & Heavy & Paint solvents as a painter \\
\hline $\begin{array}{l}\text { Coronary } \\
\text { infarction }\end{array}$ & . & $1945-1969$ & 24 & Heavy & $\begin{array}{l}\text { Many solvents as a chemist in product } \\
\text { development tasks }\end{array}$ \\
\hline $\begin{array}{l}\text { Coronary } \\
\text { infarction }\end{array}$ & . & Unknown & Unknown & Heavy & Paint solvents as a painter \\
\hline $\begin{array}{l}\text { Coronary } \\
\text { infarction }\end{array}$ & $\cdot$ & $1958-1972$ & 14 & Heavy & Paint solvents as a painter \\
\hline $\begin{array}{l}\text { Coronary } \\
\text { infarction }\end{array}$ & . & $1946-1973$ & 27 & Heavy & Paint solvents as an industrial painter \\
\hline $\begin{array}{l}\text { Coronary } \\
\text { infarction }\end{array}$ & . & $1908-1914$ & 6 & Moderate & Printing solvents as a printer \\
\hline $\begin{array}{l}\text { Coronary } \\
\text { infarction }\end{array}$ & $\cdot$ & $1948-1974$ & 26 & Moderate & $\begin{array}{l}\text { Paint solvents as a supervisor in a paint } \\
\text { factory }\end{array}$ \\
\hline $\begin{array}{l}\text { Coronary } \\
\text { infarction }\end{array}$ & $\cdot$ & $1929-1935$ & 6 & Moderate & $\begin{array}{l}\text { Various solvents, possibly chlorinated } \\
\text { hydrocarbons, as a shoe factory worker }\end{array}$ \\
\hline $\begin{array}{l}\text { Coronary } \\
\text { infarction }\end{array}$ & - & $1946-1955$ & 9 & Moderate & Paint solvents as a painter \\
\hline
\end{tabular}


Table 9. Continued.

\begin{tabular}{|c|c|c|c|c|c|}
\hline $\begin{array}{l}\text { Casel } \\
\text { referent } \\
\text { status }\end{array}$ & $\begin{array}{l}\text { Histo- } \\
\text { logy }^{\mathbf{a}}\end{array}$ & Period & $\begin{array}{l}\text { Duration } \\
\text { (years) }\end{array}$ & $\begin{array}{l}\text { Estimated } \\
\text { intensity }\end{array}$ & Type of solvent and job \\
\hline $\begin{array}{l}\text { Coronary } \\
\text { infarction }\end{array}$ & . & $1944-1971$ & 27 & Light & $\begin{array}{l}\text { Perchloroethylene (laundry, only } \\
\text { temporarily dry cleaning) }\end{array}$ \\
\hline $\begin{array}{l}\text { Coronary } \\
\text { infarction }\end{array}$ & $\cdot$ & $1930-$ & Unknown & Light & Paint solvents as a joiner \\
\hline $\begin{array}{l}\text { Coronary } \\
\text { infarction }\end{array}$ & . & $1925-1961$ & 36 & Light & Paint solvents as a joiner \\
\hline $\begin{array}{l}\text { Coronary } \\
\text { infarction }\end{array}$ & . & Unknown & 15 & Light & $\begin{array}{l}\text { Perchloroethylene as the owner of a dry } \\
\text { cleaning shop }\end{array}$ \\
\hline
\end{tabular}

a $\mathrm{H}=$ hepatocellular, $\mathrm{AS}=$ angiosarcoma, $\mathrm{AC}=$ anaplastic carcinoma.

Table 10. Odds ratios (OR) and $90 \%$ confidence intervals $(90 \% \mathrm{Cl})$ for the association between primary liver cancer and smoking ${ }^{a}$ among the male and female liver cancer cases separately, determined for the two reference groups separately and combined.

\begin{tabular}{lccccc}
\hline \multirow{2}{*}{ Reference group } & \multicolumn{3}{c}{ Liver cancer cases } \\
\cline { 2 - 3 } \cline { 6 - 7 } & \multicolumn{2}{c}{ Men } & & \multicolumn{2}{c}{ Women } \\
\cline { 2 - 3 } \cline { 5 - 7 } & OR & $90 \% \mathrm{Cl}$ & & OR & $90 \% \mathrm{Cl}$ \\
\hline Stomach cancer & 1.6 & $1.1-2.3$ & & 1.6 & $0.8-3.0$ \\
Coronary infarction & 1.3 & $0.9-1.9$ & & 0.8 & $0.4-1.5$ \\
Both groups combined & 1.4 & $1.0-2.0$ & & 1.1 & $0.7-1.9$ \\
\hline
\end{tabular}

a More than one pack of cigarettes per day.

some patients. Because many patients were old at death, it is conceivable that some had no close living relatives. It is not likely that the vital status of relatives would cause bias however. Furthermore, the proportion of the equally old referents without relatives was roughly the same. The second reason was nonresponse of located relatives. In some instances nonresponse was probably due to the old age of the person contacted. However, the nonrespondence could have been selective if relatives of patients with a low social status were more reluctant to reply. Low social status could on the other hand be associated with solvent exposure (eg, dry cleaning). Because the case and reference series were rather symmetrical also with respect to nonresponse, it is not likely that selective nonresponse was a significant source of error in this study. Besides, the direction of such a bias would be negative if this mechanism were the cause.

We controlled information bias by obscuring the case or reference status from the hygienists who coded the exposures. This measure should have eliminated any systematic classification errors. In addition the occupational histories of the women were likely to be equally accurate for the cases and referents because there were no obvious differences in the response rates or distribution of the respondents (table 4). The hypothesis of the study was not revealed to the respondent, and questions concerning exposure were not asked at all. Therefore, better recall of exposures on the part of the cases is very unlikely. In addition, it is improbable that information bias would have occurred for one sex only.

Confounding can pass undetected if the multifactorial etiology of the disease in question is not fully known and if exposure data, such as histories of a whole worklife given by relatives, are inexact. To be a confounder, a causal risk factor of the disease must

Table 11. Selected leisure-time activities of those men and women whose relatives reported leisure-time activity. Percentages calculated after missing data were excluded.

\begin{tabular}{|c|c|c|c|c|c|c|}
\hline \multirow[b]{2}{*}{ Leisure-time activity } & \multicolumn{3}{|c|}{ Men $(\%)$} & \multicolumn{3}{|c|}{ Women $(\%)$} \\
\hline & $\begin{array}{c}\text { Cases } \\
(\mathrm{N}=178)\end{array}$ & $\begin{array}{l}\text { Stomach } \\
\text { cancer } \\
\text { referents } \\
(\mathrm{N}=272)\end{array}$ & $\begin{array}{l}\text { Coronary } \\
\text { infarction } \\
\text { referents } \\
(\mathrm{N}=218)\end{array}$ & $\begin{array}{c}\text { Cases } \\
(\mathrm{N}=166)\end{array}$ & $\begin{array}{l}\text { Stomach } \\
\text { cancer } \\
\text { referents } \\
(\mathrm{N}=204)\end{array}$ & $\begin{array}{c}\text { Coronary } \\
\text { infarction } \\
\text { referents } \\
(N=167)\end{array}$ \\
\hline $\begin{array}{l}\text { Sewing of clothes or } \\
\text { weaving of carpets }\end{array}$ & 2 & 4 & 6 & 65 & 74 & 64 \\
\hline Carpentry or lacquering & 38 & 51 & 42 & 5 & 2 & 2 \\
\hline Painting & 35 & 50 & 40 & 16 & 17 & 10 \\
\hline Metal work & 17 & 14 & 14 & 2 & 2 & 1 \\
\hline $\begin{array}{l}\text { Plastics or reinforced } \\
\text { plastics work }\end{array}$ & 2 & 3 & 0 & 3 & 0 & 1 \\
\hline Car repair & 25 & 23 & 29 & 0 & 0 & 1 \\
\hline Leather work & 10 & 12 & 11 & 5 & 2 & 3 \\
\hline Gardening or farming & 66 & 76 & 70 & 66 & 80 & 69 \\
\hline
\end{tabular}


be asymmetrically distributed among the exposed and unexposed. Of the potential confounders, alcohol use is no doubt a causal risk factor for liver cancer (12), and also in this study we found a dose-dependent connection between alcohol use and liver cancer. While this finding adds credence to the reliability of the alcohol history obtained from the relatives, it does not automatically identify alcohol use as a confounder in this specific study. Underreporting of alcohol use is known to occur generally. As long as the underreporting is not asymmetrical, it should not cause bias. When the distribution of alcohol use between the exposed and unexposed (to solvents) members of the study base (note, not between cases and referents) was scrutinized, some asymmetry was evident, ie, it turned out that the exposed female cases were reported to have used less alcohol than the unexposed ones. In this study alcohol was thus a negative rather than a positive confounder.

Data on other known risk factors such as past hepatitis B infection would have completed the evaluation of potential confounding. Serology results were generally not available, however. Of the exposed female cases, two out of seven had histologically verified cirrhosis compared with 20 out of 159 unexposed female cases. On the basis of the distribution among the unexposed female cases, one case of cirrhosis would be expected among the exposed female cases. The confounding effect of the one excessive case is difficult to evaluate, however.

Because of the age distribution of the material only very few women had used contraceptives. In addition the use of other hormone preparations was rare. Such use could therefore not confound the results. Other confounding does not seem likely, either, since leisuretime activities, smoking habits, and coffee and tea drinking habits were fairly symmetrically distributed.

The fact that the results were similar irrespective of the reference category is also reassuring. The stomach cancer category was introduced to ensure symmetry of the exposure history; one may assume that relatives of cancer patients, irrespective of type, recall occupational history with the same accuracy. On the other hand, any cancer form could in principle be connected with some (yet unidentified) chemical exposure. The occurrence of this phenomenon would tend to mask existing effects. The masking of carcinogenic effects is less likely if noncancer referents are used. Therefore we employed coronary infarction as the other reference disease. The problem with using noncancer referents is that the symmetry of the history may not be perfect, although there are no strong reasons to believe that relatives of deceased infarction patients would recall the exposure history less accurately than those of cancer patients. The fact that the results obained were similar irrespective of the type of reference group used suggests that no major bias was involved.
Our third proposed explanation (10), namely, that there could be a sex difference in sensitivity to solvents, can neither be proved nor disproved in the light of our new data. However, there is another likely explanation.

Closer scrutiny of the type of solvent exposure reported reveals that, although all of the 13 female liver cancer cases had been exposed to solvent mixtures, nine (both studies combined) had been exposed to chlorinated hydrocarbons versus two of the stomach cancer referents and none of the coronary infarction referents. Hence the carcinogenic exposures may have been chlorinated hydrocarbons, of which at least trichloroethylene, perchloroethylene, and carbon tetrachloride had been used by some of the women with liver cancer. Carbon tetrachloride and perchloroethylene have been classified as possible carcinogens by the International Agency for Research on Cancer (11). The men had a largely different exposure pattern in the sense that painting had been their most common solvent exposure (table 8). Dry cleaning or other work entailing chlorinated hydrocarbon exposure was rare in the whole male study material. Hence the difference between the men and women could well be explained by differences in exposure patterns between "male" and "female" jobs in general.

Some earlier studies have also found a connection between primary liver cancer and solvent exposure. Stemhagen et al (14) found an elevated risk for liver cancer among both men and women employed as cleaning service workers. The OR was $4.3(95 \% \mathrm{CI}$ $1.2-16)$ for the women and $2.5(95 \%$ CI $1.0-6.1)$ for the men. In that study the men were also exposed to chlorinated hydrocarbons. Hardell et al (9) found a twofold increase in hepatocellular carcinoma among men exposed to "organic solvents" (among them triand perchloroethylene), and Dubrow \& Gute (6), in a proportional mortality study, found a threefold risk based on six cases among men exposed to chlorinated solvents in the jewelry industry. Blair et al (2) found an elevated risk of liver cancer in a cohort study of laundry and dry cleaning workers. However, there are also studies in which no excess risk has been demonstrated $(1,3,7,13)$. The power of the latter studies has been rather low, however. Other diluting factors may have been a nondifferential misclassification of exposure (all laundry workers are not exposed to solvents), liberal admission criteria in cohort studies, and misclassification between primary and metastatic liver cancer. It would therefore be a mistake to use these nonpositive studies as an argument against the carcinogenicity of organic solvents, especially chlorinated ones. Of the studies showing an association, at least Stemhagen et al (14) and Hardell et al (9), in addition to our team, ascertained histologically that the diagnoses really were primary, not secondary, liver cancers. This procedure improves the power of the study to detect true associations, and it may well help explain the difference in the results between different studies. 
In conclusion, the present study confirmed the results of our previous investigation by again demonstrating a connection between exposure to organic solvents, especially chlorinated hydrocarbons, and primary liver cancer in women. Although some nonpositive results have been published, our findings are also in concordance with results from four earlier studies reported by other authors. Taken together, these positive results suggest that exposure to chlorinated hydrocarbons increases the risk for primary liver cancer. The reasons for the sex difference found in our study are not completely clear but may be due to a more frequent exposure to chlorinated hydrocarbons among the women in our material.

\section{Acknowledgments}

We wish to thank the Finnish Cancer Registry for its invaluable help with collecting the preliminary information on the cases and cancer referents from its register. J Seitsamo, MSc, performed the statistical analyses, R Degerth, MSc, participated in the evaluation of exposures, and Ms P Havana helped compile the data.

\section{References}

1. Austin H, Delzell E, Grufferman S, Levine R, Morrison AS, Stolley PD, Cole P. Case-control study of hepatocellular carcinoma, occupation, and chemical exposures. J Occup Med 29 (1987) 665-669.

2. Blair A, Decouflé P, Grauman D. Causes of death among laundry and dry cleaning workers. Am J Public Health 69 (1979) 508-511.

3. Brown DP, Kaplan SD. Retrospective cohort mortality study of dry cleaner workers using perchloroethylene. J Occup Med 29 (1987) 535-541.

4. Copeland KT, Checkoway H, McMichael AJ. Bias due to misclassification in the estimation of relative risk. Am J Epidemiol 105 (1977) 488-495.

5. Cornfield J. A statistical problem arising from retrospective studies. In: University of California Press. Proceedings of the 3rd Berkeley symposium. Volume 4. Berkeley, CA 1956, pp 135-148.

6. Dubrow R, Gute DM. Cause-specific mortality among Rhode Island jewelry workers. Am J Ind Med 12 (1987) 579-593.

7. Duh R-W, Asal NR. Mortality among laundry and dry cleaning workers in Oklahoma. Am J Public Health 74 (1984) 1278-1280.

8. Gart JJ. Point interval estimation of the common odds ratio in the combination of $2 \times 2$ tables with fixed marginals. Biometrika 57 (1970) 471-475.

9. Hardell L, Bengtsson NO, Jonsson U, Eriksson S, Larsson LG. Aetiological aspects on primary liver cancer with special regard to alcohol, organic solvents and acute intermittent porphyria - An epidemiological investigation. Br J Cancer 50 (1984) 389-397.

10. Hernberg S, Korkala M-L, Asikainen U, Riala R. Primary liver cancer and exposure to solvents. Int Arch Occup Environ Health 54 (1984) 147-153.

11. International Agency for Research on Cancer. Overall evaluations of carcinogenity: An updating of IARC monographs volumes 1 to 42. Lyon 1987. (IARC monographs on the evaluation of carcinogenic risks to humans, supplement 7).

12. International Agency for Research on Cancer. Alcohol drinking. Lyon (in press). (IARC monographs on the evaluation of the carcinogenic risks to humans, volume 44).

13. Katz RM, Jowett D. Female laundry and dry cleaning workers in Wisconsin: A mortality analysis. Am J Public Health 71 (1981) 305-307.

14. Stemhagen A, Slade J, Altman R, Bill J. Occupational risk factors and liver cancer: A retrospective case-control study of primary liver cancer in New Jersey. Am J Epidemiol 117 (1983) 443—454.

Received for publication: 2 May 1988 